\title{
Advantages of a cohort study on cardiac arrest conducted by nurses*
}

\author{
Vantagens do estudo de coorte realizado por enfermeiros em parada cardiorrespiratória \\ Ventajas del estudio de cohorte llevado a cabo por enfermeros en paro cardiorrespiratorio
}

Cássia Regina Vancini Campanharo ${ }^{1}$, Rodrigo Luiz Vancini ${ }^{2}$, Maria Carolina Barbosa Teixeira Lopes ${ }^{1}$, Meiry Fernanda Pinto Okuno', Ruth Ester Assayag Batista ${ }^{1}$, Álvaro Nagib Atallah' ${ }^{3}$, Aécio Flávio Teixeira de Góis ${ }^{3}$

* Extracted from the thesis "A epidemiologia da parada cardiorrespiratória em um pronto- socorro de um hospital universitário," Universidade Federal de São Paulo, Escola Paulista de Medicina, Brazil, 2015.

${ }^{1}$ Universidade Federal de São Paulo, Escola Paulista de Enfermagem, São Paulo, SP, Brazil.

${ }^{2}$ Universidade Federal do Espírito Santo, Centro de Educação e Desportos, Vitória, ES, Brazil.

${ }^{3}$ Universidade Federal de São Paulo, Escola Paulista de Medicina, São Paulo, SP, Brazil.

\section{ABSTRACT}

Objective: Identifying factors associated to survival after cardiac arrest. Method: An experience report of a cohort study conducted in a university hospital, with a consecutive sample comprised of 285 patients. Data were collected for a year by trained nurses. The training strategy was conducted through an expository dialogue lecture. Collection monitoring was carried out by nurses via telephone calls, visits to the emergency room and by medical record searches. The neurological status of survivors was evaluated at discharge, after six months and one year. Results: Of the 285 patients, 16 survived until hospital discharge, and 13 remained alive after one year, making possible to identify factors associated with survival. There were no losses in the process. Conclusion: Cohort studies help identify risks and disease outcomes. Considering cardiac arrest, they can subsidize public policies, encourage future studies and training programs for CPR, thereby improving the prognosis of patients.

\section{DESCRIPTORS}

Heart Arrest; Cardiopulmonary Resuscitation; Survival Analysis; Nursing; Epidemiology; Cohort Studies. 


\section{INTRODUCTION}

Epidemiology is defined as the area that studies the conditions related to health or the distribution and determinants of diseases, their physical, biological, social, cultural and behavioral factors, in order to control health problems ${ }^{(1)}$.

Epidemiological studies can be divided into descriptive and analytical. Descriptive studies determine the distribution of disease or health-related conditions, according to the time, place and characteristics of individuals, meaning the when, where and who gets sick; they can be by population, case report or a series of cases ${ }^{(1)}$. Analytical studies are developed when there is a hypothesis to be tested and can be divided into experimental and observational. Observational can be transversal when the data is collected at a single moment, or longitudinal, when a follow-up study is performed on individuals over time. Longitudinal can be case-control or cohort, prospective or retrospective ${ }^{(1)}$.

Studies in the area of cardiac arrest (CA) usually focus on identifying factors associated with mortality, survival and neurological damage after $\mathrm{CA}$ over a period of time. This article aims to report the experience on the conduct of a cohort study by nurses to assess the long-term survival of patients after a CA and describe the basic concepts of this type of study.

Cardiac arrest (CA) is frequent and potentially fatal. Each year, more than 300,000 individuals are admitted to emergency services as a result of $\mathrm{CA}^{(2-3)}$.

Hospital discharge survival rates for these individuals ranges from $9.5 \%$ to $24.2 \%$, with half of the survivors suffering irreversible neurological damage ${ }^{(2)}$.

Despite the existence of guidelines for the care of CA, survival and prognosis are variable, mainly due to the heterogeneity of the population attended ${ }^{(4)}$. Thus, greater understanding of the factors associated with survival after CA can help the development of strategies to improve physical, human and material resources for the care, thereby improving results.

In this context, a prospective cohort study was conducted in a university hospital in São Paulo, with 285 patients aiming at successfully characterizing patients diagnosed with CA treated in the emergency room and identifying factors associated with survival of this population.

\section{METHOD}

The study was approved by the Ethics Committee of the Federal University of São Paulo (protocol 0030/11). Because this is an observational study and due to the difficulty in obtaining consent from patients in critical health condition and in a life-threatening situation, release of Clarified Consent was granted.

The study was conducted at Hospital São Paulo (HSP), a public teaching hospital attending to cases of high complexity. Inclusion criteria for this study were individuals treated in the adult clinical emergencies sector of HSP, diagnosed with CA (extra or intra-hospital) evidenced by lack of consciousness, breathing and central pulse. Exclusion criteria for this study were patients treated with CA diagnosis in other sectors of the HSP.
Data were collected through a standard report for collection of meaningful data in CA - In-hospital Utstein Style (5), by trained nurses. The training was conducted by the researcher through an expository lecture class with slides and dialogue about the items in the collection instrument in groups of ten people, given to the nursing staff working day and night shifts. The researcher presented the instrument variables and their meanings and applied an individual case study on the addressed topic in order to generate discussions with the team and clarify possible questions about data collection.

Data were collected from February 2011 to January 2012. The researcher monitored data collection through phone calls at the end of all shifts (morning, afternoon and two night shifts) and with daily visits to the emergency room, in which nurses doubts regarding data collection were clarified, and a search was done in the medical records if no data was collected.

After inclusion in the study, patients were followed for neurological status assessment by the Cerebral Performance Category Glasgow-Pittsburgh (CPC) ${ }^{(5)}$, at three different times - hospital discharge, after six months and after one year - by researcher visits to inpatient units, outpatient return consultations and phone calls.

$\mathrm{CPC}$ is divided into five categories: Category 1 indicates complete independence and ability to work; Category 2 indicates moderate disability, ability to work part-time and independence in the Activities of Daily Living; Category 3 indicates severe disability and total dependence for the Activities of Daily Living; Category 4 indicates a persistent vegetative state; and Category 5 indicates brain death ${ }^{(5)}$.

Variables were stored in the Excel spreadsheets program, version 2003, for further statistical analysis.

Statistical analysis was performed with the Statistical Package for the Social Sciences (SPSS) version 19 (Chicago, Illinois, United States). For continuous variables, the average, standard deviation, median, minimum and maximum were calculated. For categorical variables, frequency and percentage were calculated. If the patient had more than one CA, only the first episode was considered for inclusion in the analysis.

Survival curves in the first 24 hours until hospital discharge, 6 months and 1 year after hospital discharge were estimated using the Kaplan-Meier method and compared using log-rank test when survival curves did not intersect, and by Breslow test when the survival curves intersected.

In order to verify which variables best explained survival, multiple logistic regression was used, and Forward method was used to select those more closely associated with survival of patients. The verification of significant associations between variables was calculated by the hazard ratio (HR), where the chance of death is divided by the chance of survival. Significance level was 0.05 .

\section{RESULTS}

At the end of the study, 16 of the 285 patients survived hospital discharge and 13 survived the six months and one year follow-ups, meaning no losses during the study.

Regarding CPC evolution in patients who survived hospital discharge ( $\mathrm{n}=16), 6.3 \%$ showed CPC improvement, 
50.0\% remained with the same CPC status and $43.8 \%$ had worse CPC compared to the previous neurological status. After 6 months of follow-up, 53.8\% remained with the same CPC and 46.2\% had CPC improvement in relation to hospital discharge. After 1 year of follow-up, all patients remained with the same $\mathrm{CPC}$ as the previous 6 months.

Figure 1 is a flowchart of patient monitoring.

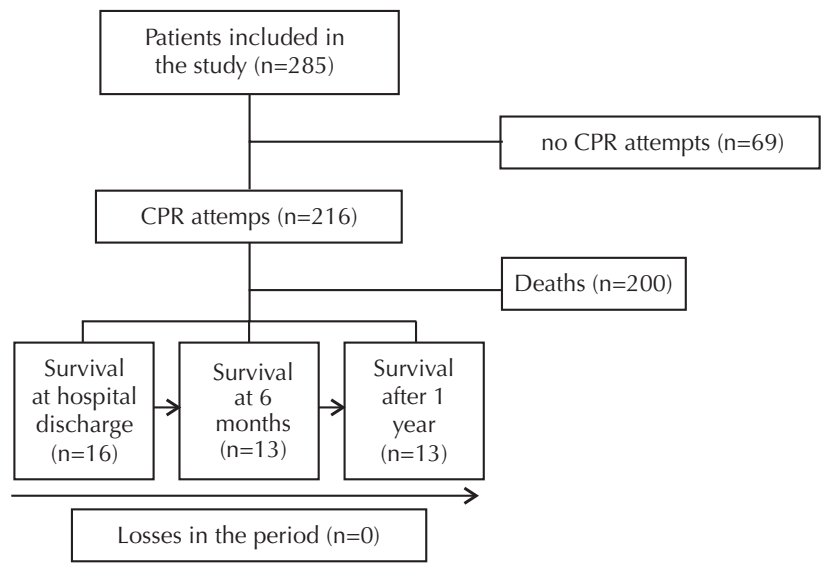

Note: CPR: Cardiopulmonary Resuscitation

Figure 1 - Flowchart of patients' monitoring in the study - São Paulo, 2011.

\section{DISCUSSION}

Cohort studies are primary, original studies, which in the health area are intended to detect disease-causing agents, etiologic studies, or precipitating factors for their installation and are used to monitor the progress of symptoms of a particular disease and its prognosis. For longitudinal studies, the term longitudinal means multiple collecting data points for a long period of time. In a longitudinal design, the ability to demonstrate changes over time and the temporal sequence of these phenomena is an essential criterion to establish the causal relationship ${ }^{(6)}$.

A cohort consists of a group of people considered healthy for the investigated disease and, in relation to some criteria, it is a homogeneous group. However, as to the variable of research, the group is heterogeneous. They are usually performed in order to describe the incidence of certain diseases or to analyze the associations between the diseases and their determinants ${ }^{(7-8)}$.

Cohort studies can be prospective concurrent, when a group of individuals is selected at the beginning of the study and followed for a period of time; or non-concurrent, when the cohort was selected at some point in the past and individuals are monitored from the present or from a recent past $^{(7)}$.

In cohort studies, participants are classified as exposed or not exposed to a certain factor of interest. Participants are to be monitored to assess the impact of this factor between exposed and unexposed, determining the incidence of the disease and its natural history between exposed and unexposed ${ }^{(7)}$.
When the exposure is frequent and the study can be prospective, there is the possibility of opting for a controlled population, so there will be no loss to follow up in the study, subsequently dividing it into two groups. In the retrospective cohort, exposure and results occurred in the past, and so the investigator must obtain the data in relation to exposure and results from medical records or interviews ${ }^{(7)}$.

To provide concrete information on the risk of a disease, a cohort study must meet the following criteria: individuals can not have the referred disease at the time they are selected; observations must go on for a significant period of time within the natural history of the disease and the members of the cohort need to be observed during the whole time of the study. Its main characteristic is the follow up of the study subjects over time to evaluate the occurrence of the outcome related or not related to the exposure to the factor of interest ${ }^{(7)}$.

A cohort study has internal validity, meaning the ability to prove that the results are specific to the sample, when there is the presence of selection biases and information, the quality of follow-up of research subjects and the presence of confounding factors prior to the study ${ }^{(7,9-12)}$.

The requirements for conducting a cohort study with internal validity are: only including individuals that have the exposure factor for the studied outcome; specific and measurable exposure factor defined by objective criteria; similarity between exposed and unexposed except for the exposure factor; obtaining information on the outcomes in the same way for exposed and unexposed; the evaluator of the outcomes must not have knowledge regarding exposure; subject follow-up should be complete and in a previously defined period with the collection of as much information as to minimize losses during follow-up, as these can reduce the statistical power of the tests and the accuracy of inferences. Follow-up discontinuity is the main cause of loss of quality in this type of study. Ways to reduce follow-up losses are: adequate sample selection, evaluating the possibility of continuing in the study, finding out most of the subject's identification data and of the people close to them; identification and control of confounding factors, which are variables that can modify the relationship between the exposure factor and the outcome. The most commonly used strategies to control confounding factors are: exclusion of individuals who have potentially confounding variables; pairing exposed and unexposed subjects; subgroup analysis and multivariate analysis techniques, in which the statistical models examine the potential effect of a variable while simultaneously controlling the effect of the others; participant sample must be of sufficient size to answer the question of the study, minimizing the occurrence of errors. Type I Error, stating that the risk factor is associated with the outcome when in fact it is not, and Type II Error, stating that the risk factor is not associated with the outcome when in fact it is; adequate statistical analysis, considering that the majority of cohort studies intend to evalu- 
ate the association between the incidence of outcome in exposed and unexposed patients. Chi-square test is often used when there are no confounding factors. If the association is significant, the degree of this association is found by calculating the Relative Risk, the ratio of the incidence of disease in exposed patients by the incidence of the disease in non-exposed patients. Thus, relative risk represents the strength of association between exposure and disease development. The higher the relative risk, the greater the certainty that the factor under study is associated with the disease.

If a cohort study results are relevant and possible causes of biases are discarded, then the search should be evaluated in relation to external validity, which is the ability to apply or generalize findings to other contexts. If patients meet the criteria for inclusion and exclusion established by the cohort study, there is no doubt as to the applicability, meaning that patients exposed to those factors will be more susceptible to experiencing the outcomes ${ }^{(8)}$.

Cohort studies are considered the best type of observational study to establish the relationship between cause and effect. The main advantages of this type of study are: direct calculation of relative risk; providing information on the incidence of the disease; demonstrating a clear temporal relationship between exposure and disease; obtaining exposure can be without the bias that might occur if the outcome was already known; they can provide information about multiple exposures and information on multiple outcomes associated with only one exposure ${ }^{(7,9,13)}$.

CA cohort studies can be useful to identify factors associated with mortality, survival and neurological status of patients over time, which can subsidize basic or advanced support services for better quality of life. Furthermore, for proper care in cases of CA, having a leader to distribute the functions and directing the team during cardiopulmonary resuscitation (CPR) is essential ${ }^{(14-15)}$.

Nurses with training in CPR techniques are one of the professionals qualified to assume a leadership role. During $\mathrm{CPR}$, this professional can supervise care and identify areas for improvement, promoting constructive interventions and training in CPR maneuvers through subsequent continued and permanent education ${ }^{(16-18)}$.

The main limitation for conducting cohort studies in addition to cost is the loss of participants during follow-up due to continuity refusal or address and/or telephone changes. Costs and difficulties of enforcement may jeopardize the development of these studies, mainly because they require large numbers of participants and long follow-up periods to establish associations. Other disadvantages are: inefficiency in studying rare diseases, difficulty to follow-up, and changes in diagnostic methods over time, which could bias the study ${ }^{(7,9)}$.

\section{CONCLUSION}

Cohort studies are important for the understanding of the risk factors associated with numerous diseases, the incidence rates of outcomes and the natural evolution of diseases and patients.

Regarding its application in CA cases, despite advances having been made in CPR techniques, mortality rates have had no significant decrease in recent decades, posing a challenge for researchers in this field.

Conducting cohort studies with these patients can support the creation of public policies, encouraging future research and the establishment of training and education programs in CPR for health professionals, care providers, as well as for the general population. It is likely that increased CPR knowledge among health professionals and the general population may improve patient survival.

\section{RESUMO}

Objetivo: Identificar fatores associados à sobrevida após parada cardiorrespiratória. Método: Relato de experiência sobre a realização de estudo de coorte em um hospital universitário, cuja amostra consecutiva foi composta por 285 pacientes. Os dados foram coletados durante um ano por enfermeiras treinadas. A estratégia de treinamento foi a aula expositiva dialogada. O monitoramento da coleta foi realizado pelos enfermeiros por ligações telefônicas, visitas ao pronto-socorro e busca nos prontuários. O estado neurológico dos sobreviventes foi avaliado na alta, após seis meses e um ano. Resultados: Dos 285 pacientes, 16 sobreviveram à alta e 13 permaneceram vivos após um ano, sendo possível identificar fatores associados à sobrevivência. Não houve perdas no seguimento. Conclusão: Estudos de coorte auxiliam na identificação dos riscos e desfechos de doenças. Na parada cardiorrespiratória podem subsidiar políticas públicas, incentivar pesquisas futuras e programas de treinamento em ressuscitação cardiopulmonar, melhorando o prognóstico dos pacientes.

\section{DESCRITORES}

Parada Cardíaca; Ressuscitação Cardiopulmonar; Análise de Sobrevida; Enfermagem; Epidemiologia; Estudos de Coorte.

\section{RESUMEN}

Objetivo: Identificar los factores asociados con la supervivencia luego de paro cardiorrespiratorio. Método: Relato de experiencia acerca de la realización de estudio de cohorte en un hospital universitario, cuya muestra consecutiva estuvo compuesta de 285 pacientes. Los datos los recogieron durante un año las enfermeras entrenadas. La estrategia de entrenamiento fue la clase expositiva dialogada. El monitoreo de la recolección lo realizaron los enfermeros mediante llamadas por teléfono, visitas al servicio de urgencias y búsqueda en las fichas. El estado neurológico de los supervivientes fue valorado en el alta, después de seis meses y un año. Resultados: De los 285 pacientes, 16 sobrevivieron al alta y 13 permanecieron vivos después de un año, siendo posible identificar factores asociados con la supervivencia. No hubo pérdidas en el seguimiento. Conclusión: Estudios de cohorte ayudaron la identificación de los riesgos y resultados de enfermedades. En lo que se refiere al paro cardiorrespiratorio pueden subsidiar políticas públicas, incentivar investigaciones futuras y programas de entrenamiento en resucitación cardiopulmonar, mejorando el pronóstico de los pacientes.

Paro Cardíaco; Resucitación Cardiopulmonar; Análisis de Supervivencia; Enfermería; Epidemiología; Estudios de Cohortes. 


\section{REFERENCES}

1. Lima-Costa MF. Tipos de estudos epidemiológicos: conceitos básicos e aplicações na área do envelhecimento. Epidemiol Serv Saúde. 2003;12(4):189-201

2. Gräsner JT, Bossaert L. Epidemiology and management of cardiac arrest: what registries are revealing. Best Pract Res Clin Anaesthesiol. 2013;27(3):293-306

3. Go AS, Mozaffarian D, Roger VL, Benjamin EJ, Berry JD, Borden WB, et al.; American Heart Association Statistics Committee and Stroke Statistics Subcommittee. Heart disease and stroke statistics - 2013 update: a report from the American Heart Association. Circulation. 2013;127(1):e6-e245.

4. Timerman S, Ramires JAF. Morte súbita: aspectos epidemiológicos. Rev Soc Cardiol. Estado de São Paulo. 2006;16(1):8-23.

5. Avansi PA, Meneghin P. Translation and adaptation of the In-Hospital Utstein Style into the portuguese language. Rev Esc Enferm USP. 2008;42(3):504-11.

6. Polit DF, Beck CT, Hungler BP. Fundamentos de pesquisa em enfermagem: métodos, avaliação e utilização. Porto Alegre: Artmed; 2004.

7. Fernandes SM, Carneiro AV. Tipos de estudos clínicos. II. Estudos de coorte. Rev Port Cardiol. 2005;24(9):1151-8.

8. Suzumura EA, Oliveira JB, Buehler AM, Carballo M, Berwanger O. Como avaliar criticamente estudos de coorte em terapia intensiva. Rev Bras Ter Intensiva. 2008;20(1):93-8.

9. Fletcher RH, Fletcher SW. Epidemiologia clínica: elementos essenciais. Porto Alegre: Artmed; 2003.

10. Grimes DA, Schulz KF. Cohort studies: marching towards outcomes. Lancet. 2002;359(9303):341-5.

11. Haddad N. Metodologia de estudos em ciências da saúde: como planejar, analisar e apresentar um trabalho científico. São Paulo: Roca; 2004. Delineamento de estudos analíticos; p. 39-70.

12. Grimes DA, Schulz KF. Bias and causal associations in observational research. Lancet. 2002;359(9302):248-52.

13. Arnaout M, Mongardon N, Deye N, Legriel S, Dumas F, Sauneuf B, et al. Out-of-hospital cardiac arrest from brain cause: epidemiology, clinical features, and outcome in a multicenter cohort*. Crit Care Med. 2015;43(2):453-60.

14. Wolfe H, Zebuhr C, Topjian AA, Nishisaki A, Niles DE, Meaney PA, et al. Interdisciplinary ICU cardiac arrest debriefing improves survival outcomes. Crit Care Med. 2014;42(7):1688-95.

15. Peace JM, Yuen TC, Borak MH, Edelson DP. Tablet-based cardiac arrest documentation: a pilot study. Resuscitation. 2014;85(2):266-9.

16. Brião RC, Souza EM, Castro RA, Rabelo ER. Cohort study to evaluate nursing team performance in a theoretical test after training in cardiopulmonary arrest. Rev Lat Am Enfermagem. 2009;17(1):40-45.

17. Lima SG, Macedo LA, Vidal ML, Sá MP. Permanent Education in BLS and ACLS: impact on the knowledge of nursing professionals. Arq Bras Cardiol. 2009;93(6):630-6.

18. Blewer AL, Delfin G, Leary M, Gaieski DF, Abella BS. A structured educational intervention to improve targeted temperature management utilization after cardiac arrest. J Crit Care. 2013;28(3):259-64. 